\title{
Submarine groundwater discharge of nutrients to the ocean along a coastal lagoon barrier, Southern Brazil
}

\author{
L. Felipe H. Niencheski ${ }^{a}$, Herbert L. Windom ${ }^{b, *}$, Willard S. Moore ${ }^{c}$, Richard A. Jahnke ${ }^{b}$ \\ a Department of Chemistry, Fundação Universidade Federal do Rio Grande, Brazil \\ b Skidaway Institute of Oceanography, 10 Ocean Science Circle, Savannah, GA 31411, USA \\ c Department of Geological Sciences, University of South Carolina, Columbia, SC 29208, USA
}

Received 6 March 2007; received in revised form 31 May 2007; accepted 8 June 2007

Available online 20 June 2007

\begin{abstract}
The Patos-Mirim Lagoon system along the southern coast of Brazil is linked to the coastal ocean by a narrow mouth and by groundwater transport through a Holocene barrier. Although other groundwater systems are apparently active in this region, the hydraulic head of the lagoon, the largest in South America, drives groundwater transport to the coast. Water levels in wells placed in the barrier respond to changing water level in the lagoon. The wells also provide a measure of the nutrient concentrations of groundwater flowing toward the ocean. Additionally, temporary well points were used to obtain nutrient samples in groundwater on the beach face of the barrier. These samples revealed a subterranean freshwater-seawater mixing zone over a ca. $240 \mathrm{~km}$ shoreline. Previously published results of radium isotopic analyses of groundwater and of surface water from cross-shelf transects were used to estimate a water flux of submarine groundwater discharge (SGD) to nearshore surface waters of $8.5 \times 10^{7} \mathrm{~m}^{3} /$ day. Using this SGD and the nutrient concentrations in different compartments, nutrient fluxes between groundwater and surface water were estimated. Fluxes were computed using both average and median reservoir (i.e. groundwater and surface water) nutrient concentrations. The SGD total dissolved inorganic nitrogen, phosphate and silicate fluxes $\left(2.42,0.52,5.92 \times 10^{6} \mathrm{~mol} \mathrm{day}^{-1}\right.$, respectively) may represent as much as $55 \%$ (total $\mathrm{N}$ ) to $10 \%(\mathrm{Si})$ of the nutrient fluxes to the adjacent shelf environment. Assuming nitrogen limitation, SGD may be capable of supporting a production rate of $c a .3000 \mathrm{~g} \mathrm{C} \mathrm{m}^{2}$ year $^{-1}$ in the nearshore surf zone in this region.
\end{abstract}

(C) 2007 Elsevier B.V. All rights reserved.

Keywords: Nutrients; SGD; Groundwater; Coastal; Marine; Brazil; S. Atlantic Ocean

\section{Introduction}

There is a growing body of evidence indicating the importance of groundwater pathways for the transport of

\footnotetext{
* Corresponding author.

E-mail addresses: dqmhidro@furg.br (L.F.H. Niencheski), herb.windom@skio.usg.edu (H.L. Windom), moore@mail.geol.sc.edu (W.S. Moore), rick.jahnke@skio.usg.edu (R.A. Jahnke)
}

solutes in permeable sediments and aquifers at the landsea boundary. Inputs may consist of freshwater, seawater-freshwater mixtures and/or recirculated seawater; these are collectively referred to as submarine groundwater discharge (SGD).

Whether SGD originates in freshwater aquifers or includes, or is dominated by infiltrated seawater, its effect on the coastal ocean can be significant. Groundwater discharge from coastal aquifers can transport material to the ocean from land, in addition to rivers, and 
often at much higher concentrations. For example, nutrient enrichments of coastal waters have been attributed to groundwater input by a number of researchers (D'Elia et al., 1981; Simmons, 1992; Corbett et al., 1999; Rutkowski et al., 1999) and can result in significant impacts on ecosystems. Jahnke et al. (2003), observed that nutrient fluxes from estuarine sediments exceed that which could be explained by local microbial remineralization, and suggested that coastal water advection through permeable sediments was the responsible mechanism.

Although most attention has been focused on the groundwater pathway for the transport of nutrients, the potential importance in the transport of other materials at land-sea interfaces by this mechanism is apparent. As pointed out by Moore (1999) and Charrette and Sholkovitz (2006), coastal aquifers and permeable sediments provide a reaction zone where freshwater and seawater mix, similar to the surface estuarine mixing zone. In this "subterranean estuary", water flows through and reacts with stationary solid phases and the freshwater-seawater front migrates in response to seasonal and tidal water level and groundwater hydraulic gradients. Obviously, regional and global changes in sea level also influence coastal groundwater systems and the importance of SGD at the land-sea boundary.

Understanding the significance of groundwater pathways on material transport and fate at the land-sea interface will likely advance based on studies of specific coastal systems. However, if the results of these studies are to be extrapolated globally, the systems chosen should be representative of a common type of land-sea boundary. Thirteen percent of the world's coastline is occupied by coastal lagoons (Barnes, 1980). A coastal lagoon is "an area of salt or brackish water separated from the adjacent sea by a low-lying sand or shingle barrier" (Barnes, 1980). These barriers obviously impede surface exchange between the lagoon and the sea but may be very permeable, conditions which favor groundwater transport pathways.

In addition to being a quantitatively important land-sea interface, coastal lagoons are a focus of human activities. They are often adjacent to large human populations, and support a number of recreational and commercial uses such as maritime transportation and fisheries. Because of this, there has been considerable interest in understanding the relation between natural processes that affect nutrient input and cycling, and fisheries, and assessing the impact of human activities on the natural functioning of coastal lagoons. There have been literally hundreds of papers written on coastal lagoons during the past two decades that focus on these subjects, yet only a handful address any influence of groundwater pathways on processes. Examples include Johannes and Hearn (1985) who determined that SGD accounts for the major input of silicate and nitrogen to a coastal lagoon off Western Australia, and Herrera-Silveira (1998) who reported similar findings for a tropical lagoon on the coast of Mexico. In both studies, the input was associated with a coastal aquifer. But, virtually no attention was given to exchange at the ocean boundary (i.e. barrier) in these studies, and to our knowledge, no other studies of nutrient budgets or other material transport and fate in coastal lagoon systems have addressed this.

We initiated a study of groundwater-surface water interactions associated with Patos Lagoon, on the extreme southern coast of Brazil, in an attempt to understand better the exchange processes involving groundwater pathways in permeable sediments. A part of this study attempted to determine how nutrients are transported in the subterranean freshwater-seawater mixing zone, which connects the lagoon to the adjacent ocean. The Patos Lagoon system is relatively pristine, with little human development surrounding it, especially on the barrier spit separating it from the sea. Because the barrier is composed dominantly of sand, agriculture is limited to tree farms, cattle, and minimal row crops. Given the geological and hydrological characteristics of the Patos Lagoon system, we hypothesized that a relatively large amount of freshwater flow must occur through the barrier, where it mixes with sea water within the permeable sediments underlying the barrier spit. We initiated this research effort after a preliminary study of samples from a well on the barrier revealed that seawater and freshwater were mixing beneath (Windom and Niencheski, 2003) indicating the potential importance to this system of exchange through permeable sediments. Here we report the results of nutrient analyses of groundwater recovered from permanent wells installed within the lagoon barrier and from temporary well points deployed along the adjacent beach face. These results are compared to nutrient concentrations measured in the adjacent surf zone and shelf waters. Constrained by previously reported coastal residence times determined by Ra measurements (Windom et al., 2006), a simple conceptual model is used to quantify the nutrient flux to the adjacent nearshore zone.

\section{Study site}

A barrier system formed during the Holocene PostGlacial Marine Transgression occupies the entire $625 \mathrm{~km}$ coastline of the Brazilian State of Rio Grande do Sul (Dillenburg et al., 2002). The Patos-Mirim Lagoon system represents the major coastal expression 
of this barrier complex (Fig. 1), covering an area of over $10,000 \mathrm{~km}^{2}$. The only permanent surface contact with the sea is a relatively small inlet (approx. $800 \mathrm{~m}$ wide) near the city of Rio Grande. This also provides the major surface outlet for Mirim Lagoon, which drains through the Sao Goncalo Channel, into the Patos Lagoon.

The average freshwater discharge to Patos Lagoon (of which $c a .90 \%$ is from the Guaiba River) is $4000 \mathrm{~m}^{3} \mathrm{~s}^{-1}$
(Kjerfve, 1986). During periods of high runoff, the discharge can reach extremes of c. $25,000 \mathrm{~m}^{3} \mathrm{~s}^{-1}$ (Herz, 1997), which is about equal to the average discharge of the Parana River in Argentina, having the tenth highest discharge of world rivers (Todd, 1970).

High discharge occurs in the winter (June-August) during which the entire lagoon system is fresh. During these periods, circulation within the Patos Lagoon is

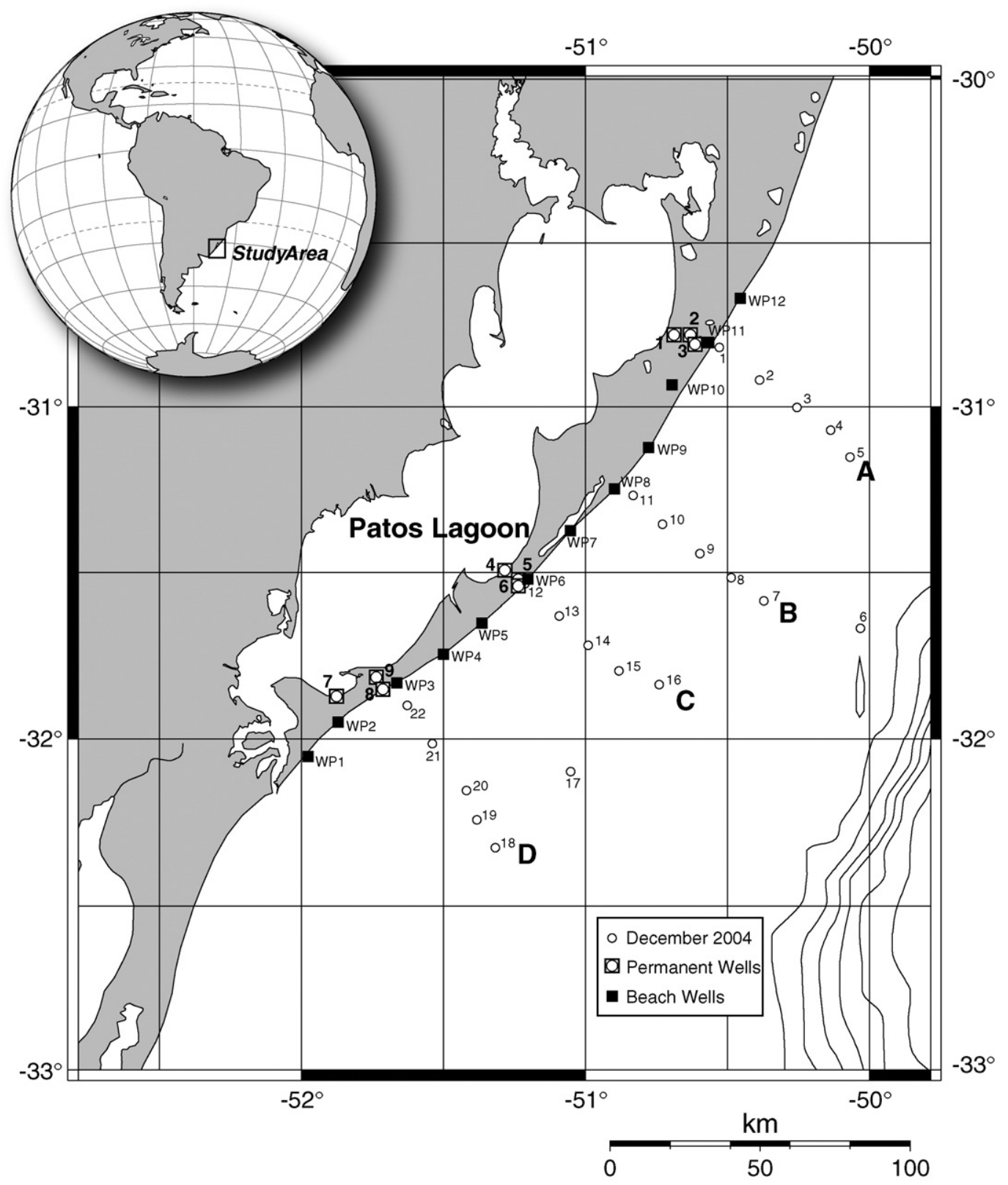

Fig. 1. Patos-Mirim Lagoon system. The Mirim Lagoon is partially shown in the lower left corner of the figure. Its only outlet to the ocean is through the Patos Lagoon. Map of the study area shows locations of permanent wells, beach groundwater and surf zone stations and offshore hydrographic and water sampling stations. The latter is located along four transect referred to in the text, starting from the north, as Transects, A, B, C and D. 
driven by fresh water discharge (Moller et al., 2001), whereas wind drives circulation at other times (Moller et al., 2001, 1996). Tides (generally about $0.5 \mathrm{~m}$ ) exert little control on circulation or water level within the lagoon except at its entrance near Rio Grande. But winds and freshwater discharge can result in seasonally significant up-set and down-set of water levels. Generally, however, the water level of the lagoon is always $0.5 \mathrm{~m}$ or more above the adjacent Atlantic over most of the Lagoon.

The water balance for choked lagoons, similar to the Patos, often take into account freshwater seepage inputs along with surface phenomena (runoff, rainfall, evaporation and surface exchange with the coastal ocean) (Knoppers and Kjerfve, 1999), but virtually never consider groundwater exchanges with the coastal ocean. The same has been true for the Patos-Mirim Lagoon system.

Patos Lagoon has a mean depth of about $6 \mathrm{~m}$ and a well mixed water column virtually year round. Bottom sediments vary from coarse sands to silts, but coarse sediments dominate (Calliari et al., 1980). The barrier spit, which separates the lagoon from the sea, is composed of relic clastic coarse grain material including shell hash with less rare interbedded finer grain lagoonal deposits (Dillenburg et al., 2002). Maximum elevations of the barrier occur along the axis and are up to $c a .20 \mathrm{~m}$, but average elevations are only a few meters above sea level.

The surf zone on the ocean side of the barrier has chlorophyll $a$ concentrations up to $1647 \mu \mathrm{g} \mathrm{L}^{-1}$ and is characterized by brown colored, often extensive, patches of the surf-zone diatom Asterionellopsis glacialis, with cell concentrations of up to $10^{8}$ cells $\mathrm{L}^{-1}$. Although no detailed study of the mechanism related to patch formation is available for this system, blooms are suggested to be associated with rainy periods and southerly winds (Odebrecht et al., 1995). Gianuca (1983) suggested that the formation of A. glacialis blooms was favored by nutrients released from resuspended sediment and through the discharge of many freshwater creeks draining inland marshes behind the dunes after heavy rainfall. But our results suggest that SGD may be a more important mechanism for supplying nutrients. During repeated sampling trips, we have observed these algae patches, virtually uninterrupted, along the entire length of our study area, regardless of season or wind direction.

\section{Field and laboratory methods}

Major field sampling campaigns were conducted during the Austral summer (November 2003 and December 2004) when freshwater discharge to the Patos
Lagoon is minimal and the salinity of the outflow at its mouth is high (Windom and Niencheski, 1994). Data on wind direction and velocity for one week prior and the week during our field campaigns were obtained from a meteorological station at the Fundação Universidade Federal do Rio Grande (FURG) near the mouth of the lagoon. During the November, 2003 campaign mean wind direction was onshore for 4 days with maximum velocities of $6 \mathrm{~m} \mathrm{~s}^{-1}$, from the south 2 days at less than $2 \mathrm{~m} \cdot \mathrm{s}^{-1}$, and from the north 9 days at $c a .3 \mathrm{~m} \mathrm{~s}^{-1}$. During the December, 2004 campaign mean wind direction was onshore 4 days at $2-4 \mathrm{~m} \mathrm{~s}^{-1}$ and 10 days from the north at $2-5 \mathrm{~m} \mathrm{~s}^{-1}$. The Rio de la Plata and Guaiba River discharges are also lowest during the Austral summer and the southward along-shore wind stress further minimizes the intrusion of any freshwater from these sources into the study area under these conditions (Piola et al., 2005).

Sampling of the coastal aquifer (i.e. groundwater of the barrier sands) was accomplished by installing PVC, screened permanent wells across three transects of the Patos Lagoon barrier (PLB). Each transect consists of three sets of wells, one near the lagoon, one in the interior and one near the beach front (Fig. 1). Each set generally included three wells screened nominally at $5 \mathrm{~m}, 10 \mathrm{~m}$ and $15 \mathrm{~m}$. Samples were collected from each well during the major field campaigns in November, 2003 and December, 2004, as well as during January 7-9, 2004; March 29-31, 2004; July 7-10, 2004; October 13-15, 2004; February 18-21, 2005; June 28-30, 2005 and January 3-5, 2006.

We used a drive-point peizometer system, similar to that used by Charette and Sholkovitz (2006), to sample groundwater along the beach of the PLB down to a maximum depth of $8 \mathrm{~m}$, but most samples were collected at shallower depths of 1-2 $\mathrm{m}$. Sampling sites were spaced at $c a .20 \mathrm{~km}$ intervals on the southernmost $240 \mathrm{~km}$ of the PLB ocean beach (Fig. 1).

Offshore seawater samples were collected in December 2004 along four transects perpendicular to shore using the research vessel Atlantico Sul (Fig. 1). CTD casts were made at each station using a Sea Bird Model 25 Sea Logger.

Samples for nutrients analyses were collected from wells and offshore by two separate peristaltic pumping systems that use a single length of acid $(\mathrm{HCl})$ cleaned silicone tubing connected directly to disposable cartridge filters. For offshore samples, the intake end of the tubing was fitted with a Teflon vane, which oriented into the current. This was hung on Kevlar rope and deployed at a depth of $5 \mathrm{~m}$ or more to be significantly below the keel of the ship. Samples were pumped directly through Aqua Prep 600, $0.45 \mu \mathrm{m}$ cartridge filters after flushing the 
tubing and the filter with several liters of sample water for permanent well and offshore samples. For surf zone and beach groundwater samples the system was flushed with less water because of filter clogging. In-line filtered samples were collected directly into $2-100 \mathrm{~mL}$ precleaned linear polyethylene bottles, after rinsing, and stored in plastic bags on ice to return to FURG for analysis.

The drive-point piezometer system consisted of stainless steel pipe sections through which a Teflon tube was passed and connected to a stainless steel, screened intake end. Samples were collected, as described above, using a peristaltic pumping system whereby samples were filtered as they were collected. Surf zone samples were collected by wading to a depth of about $1 \mathrm{~m}$ and using an acid $(\mathrm{HCl})$ cleaned $4 \mathrm{~L}$ polyethylene bottle after rinsing with ambient water. Aliquots of this water were collected as described above, using the peristaltic pumping system connected to the cartridge filters so that samples were pumped and filtered from the collecting bottle within minutes of collection.

Nutrients were analyzed colorimetrically: nitrate, phosphate, and silicate using the method of Strickland and Parsons (1965) and ammonia using the method of Aminot and Chaussepied (1983). Our estimates of the precision of the analyses are: phosphate, $\pm 0.03 \mu \mathrm{M}$; silicate, $\pm 0.15 \mu \mathrm{M}$; ammonia, $\pm 0.1 \mu \mathrm{M}$; nitrite, $\pm 0.02 \mu \mathrm{M}$; nitrate, $\pm 0.05 \mu \mathrm{M}$.

\section{Results}

\subsection{Coastal groundwater aquifer system}

Our initial conceptual model of this system assumed that freshwater from the Lagoon advects through the permeable sands of the barrier spit in response to a hydrologic head created by the lagoon. Water levels in the lagoon reach up to $3 \mathrm{~m}$ above sea level as a result of wind stress and runoff, but are always above sea level virtually throughout the Lagoon (Windom and Niencheski, 2003). Once wells on the barrier were in place, however, it became clear that the system is more complex because some wells near the lagoon exhibited artesian flow, with a hydraulic head up to a few meters above the adjacent lagoon water level. For example, one well (Well site 4, $15 \mathrm{~m}$ depth) near the lagoon, exhibited continuous flow with a hydraulic head that reached $c a$. 3 to $8 \mathrm{~m}$ above the level of the lagoon. Variations in the height of the head had no relation to the lagoon water level (Fig. 2).

During the period July 2005 and January 2006 we installed 4 temperature-pressure sensors (Hobo Water Level Loggers) in four wells to assess their response to lagoon water level. The wells chosen were at well sites 5 and 9 , in the middle of the barrier and on the southern, ocean side (Fig. 1) respectively, and at depths of 10 and $15 \mathrm{~m}$. The results (Fig. 3) show that the wells at $10 \mathrm{~m}$ depth, at both sites, respond to Patos Lagoon water level while the deeper wells do not. These latter two wells likely penetrate the same aquifer as the $15 \mathrm{~m}$ well at site 4 but because they were placed at higher elevation locations (i.e. approximately $10 \mathrm{~m}$ and $6 \mathrm{~m}$ above sea level, respectively, as compared to site 4 , which was about $2 \mathrm{~m}$ above sea level) they did not flow. This suggests that two different groundwater systems are active under the barrier: one, a surficial unconfined aquifer, which responds to the lagoon water level, and another, which is perhaps more regional.

The Guarani aquifer, which underlies virtually all of southern Brazil, Uruguay, Paraguay, and northern Argentina, is one of the largest fresh groundwater systems in the world (Araújo et al., 1999) and may be, in part, the source for a the deeper groundwater. Although,

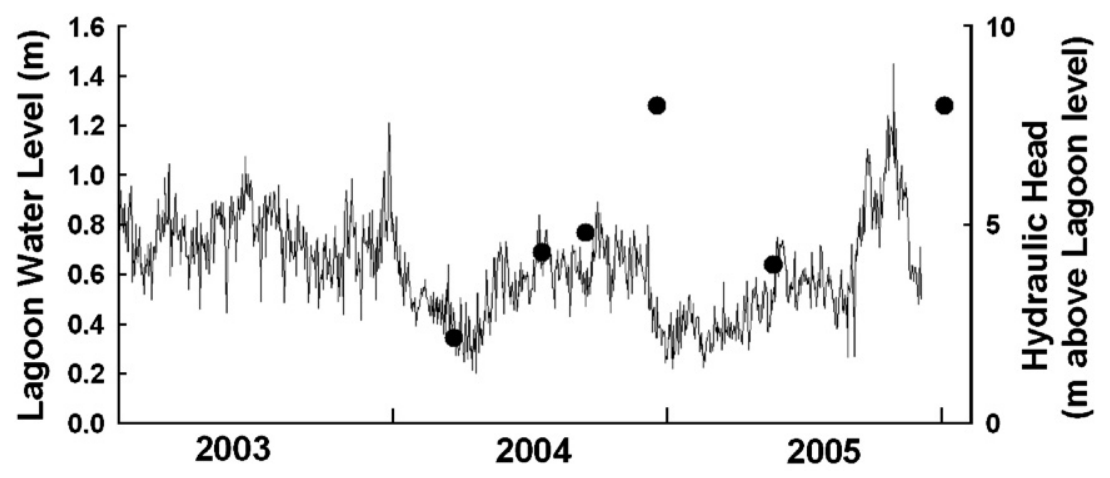

Fig. 2. Patos Lagoon's water level (line) and hydraulic head (solid circles) relative to Lagoon level obtained from the permanent well number $4,15 \mathrm{~m}$ deep. 


\section{Meters}
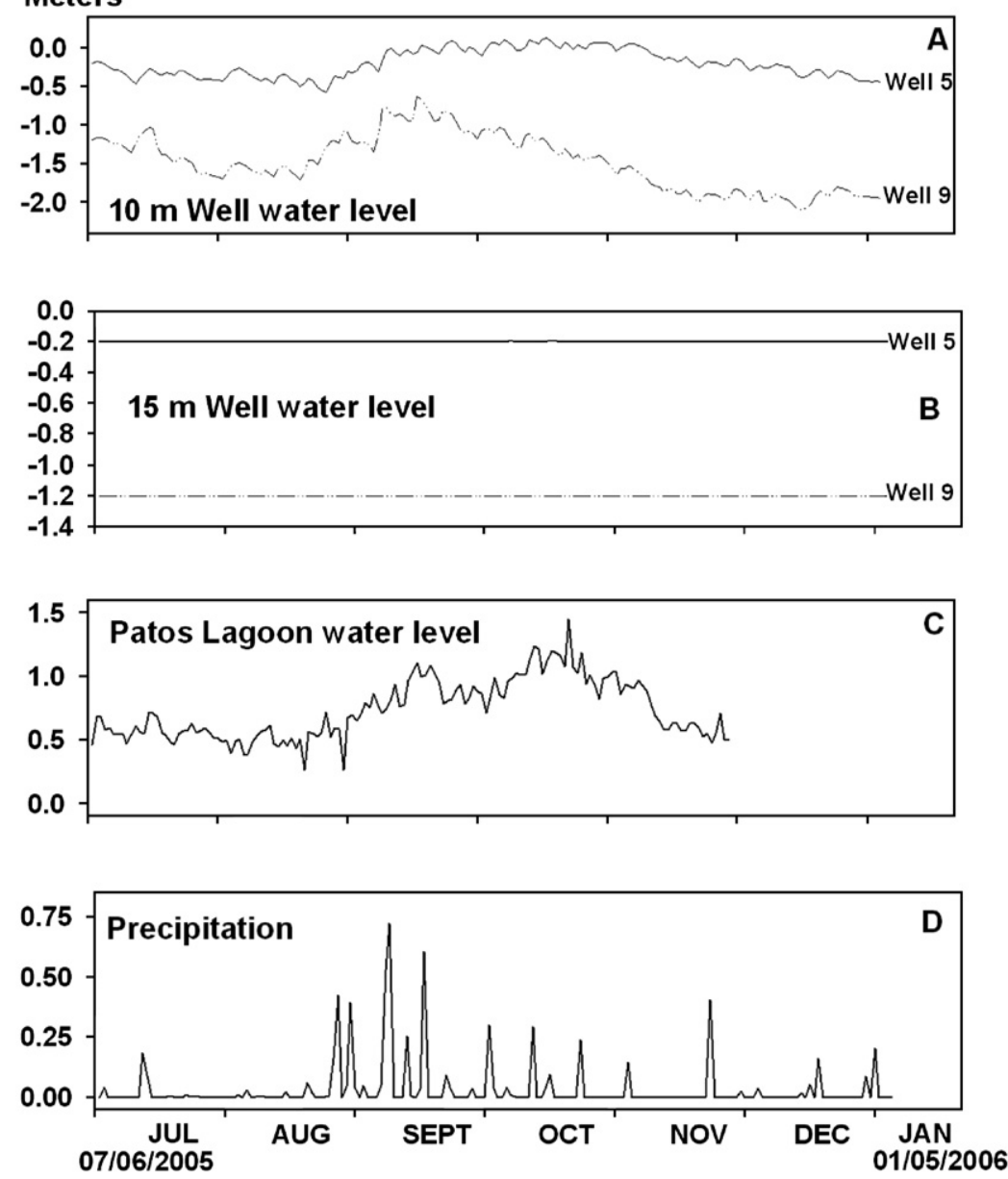

Fig. 3. Water level measured by pressure sensors (A and B) in the permanent wells, Patos Lagoon's water level (C), and precipitation rate (D) from July 06, 2005 until January 05, 2006.

Araujo et al. argue that most of the flow in this system is to the southwest, toward the Parana basin, and suggest that "negligible discharge" is to the Atlantic, they present no data to indicate what that volume might be.

The observation of artesian flow may be associated with such a regional aquifer and indicates the presence of confining sedimentary layers, which can complicate the interpretation of the well chemistry and exchanges. For example a hydraulic head greater than the level of the lagoon suggests that flow could be both toward the Atlantic and toward the lagoon. Regardless, the PatosMirim Lagoon system clearly produces local hydraulic gradients resulting in groundwater flowing in the upper aquifer toward the South Atlantic along a ca. $600 \mathrm{~km}$ length of coastline. And although there may be additional sources contributing to the lagoon as well as the ocean, in this paper we only consider the flow toward the ocean.

\subsection{Nutrients in permanent wells}

Before collecting water samples for analysis, the wells were pumped to clear the volume of the PVC pipe. Water was pumped through a chamber which contained $\mathrm{pH}, \mathrm{DO}$ and temperature sensors. This sensor system was calibrated using the manufacturer's protocol using standard solutions for $\mathrm{pH}$ and air saturated water for DO. For all wells, DO always registered around $30 \mu \mathrm{M}$ but we assume that this is an upper limit because of the chance of aeration during pumping (samples for Winkler method) and/or because we were using a Clark Cell DO sensor, which has a long equilibration time at low DO. The $\mathrm{pH}$ varied from 4.7 to 7.1 with a 
mean of 6.1. All samples were fresh (i.e. salinity $<0.1$ ) with the exception of a few samples collected from wells at stations 6 and 9, near the ocean side of the barrier, which had salinities of over 0.1 . The average conductivity in the wells at station 9 exhibited a gradient increasing with depth, which is similar to the salinity gradient observed by us previously from a temporary well nearby (Windom and Niencheski, 2003).

Nutrient concentrations showed no relation to $\mathrm{pH}$ and ranged from $0.1-180 \mu \mathrm{M}$ for ammonium, $0.02-$ $2.81 \mu \mathrm{M}$ for nitrite, $0.05-47.99 \mu \mathrm{M}$ for nitrate, 0.04 $68 \mu \mathrm{M}$ for phosphate and $0.7-2050 \mu \mathrm{M}$ for silicate. Average concentrations and standard deviations are presented in Table 1 for samples collected during the nine sampling campaigns for each well. These elevated nutrient concentrations for the fresh groundwater of the barrier were expected to be elevated above local surface waters, given our previous results obtain from samples from an exploratory well near Station 9 collected in 2001 (Windom and Niencheski, 2003). Although there was no systematic relationship between nutrient levels and other factors such as local anthropogenic source and season, concentrations did appear to relate to the specific collection site with highest concentrations always found at given well sites, while lowest concentrations were observed at other sites. The overall mean and median nutrient concentrations for the wells are also provided in Table 1 and indicate that for phosphate, ammonium and nitrite, the distributions of concentrations among the population of samples are skewed toward higher levels. For silicate and nitrate, however, the concentration distribution appears to be relatively normally distributed.

\subsection{Beach groundwater and surf zone}

Groundwater samples collected along the beach (Fig. 1) had a salinity range of 0 to $c a$. 34, with no consistent trend with distance from the mouth of the lagoon. Like the well water, these waters always had dissolved oxygen levels that we estimate to be lower than $30 \mu \mathrm{M}$. For the 6 profiles for which we collected samples at $1 \mathrm{~m}$ intervals to a depth of $>4 \mathrm{~m}$, salinities were highest in the surface samples for four of the

Table 1

Nutrient concentrations (micromoles/liter), $\mathrm{pH}$ and conductivity $(\mu \mathrm{S})$ in the permanent wells: mean and standard deviation of nine samples each

\begin{tabular}{|c|c|c|c|c|c|c|c|c|c|c|c|c|c|c|c|}
\hline \multirow{2}{*}{\multicolumn{2}{|c|}{$\begin{array}{l}\text { Depth } \\
\text { meters }\end{array}$}} & \multicolumn{2}{|l|}{$\mathrm{pH}$} & \multicolumn{2}{|c|}{ Conductivity } & \multicolumn{2}{|c|}{ Phosphate } & \multicolumn{2}{|c|}{ Silicate } & \multicolumn{2}{|c|}{ Ammonium } & \multicolumn{2}{|c|}{ Nitrite } & \multicolumn{2}{|l|}{ Nitrate } \\
\hline & & AVG & STD & AVG & STD & AVG & STD & AVG & STD & AVG & STD & AVG & STD & AVG & STD \\
\hline \multirow[t]{3}{*}{1} & 5 & 6.80 & 0.35 & 482 & 202 & 4.59 & 2.11 & 1031 & 386 & 20.8 & 8.4 & 0.25 & 0.1 & 1.26 & 1.46 \\
\hline & 10 & 6.98 & 0.35 & 577 & 40 & 4.96 & 1.34 & 1076 & 566 & 19.6 & 8.7 & 0.18 & 0.04 & 1.05 & 1.42 \\
\hline & 15 & 7.00 & 0.23 & 943 & 109 & 5.10 & 1.06 & 1040 & 339 & 15.2 & 11.1 & 0.41 & 0.76 & 1.73 & 2.63 \\
\hline \multirow[t]{3}{*}{2} & 5 & 5.66 & 0.27 & 222 & 111 & 0.44 & 0.22 & 371 & 286 & 7.2 & 7.8 & 0.42 & 0.74 & 1 & 0.82 \\
\hline & 10 & 5.61 & 0.30 & 204 & 22 & 1.18 & 1.76 & 512 & 589 & 13.0 & 24.2 & 0.17 & 0.06 & 0.87 & 0.8 \\
\hline & 15 & 5.75 & 0.33 & 176 & 48 & 4.69 & 9.18 & 538 & 259 & 25.9 & 36.4 & 0.74 & 0.41 & 1.04 & 1.19 \\
\hline \multirow[t]{3}{*}{3} & 5 & 6.43 & 0.49 & 189 & 25 & 2.60 & 0.93 & 720 & 219 & 11.3 & 5.4 & 0.29 & 0.07 & 4.23 & 8.87 \\
\hline & 10 & 6.44 & 0.41 & 171 & 10 & 7.35 & 3.87 & 921 & 273 & 14.2 & 6.1 & 0.51 & 0.19 & 1.56 & 2.35 \\
\hline & 15 & 6.42 & 0.22 & 197 & 11 & 4.09 & 2.39 & 822 & 291 & 15.9 & 6.6 & 0.59 & 0.17 & 2.37 & 4.79 \\
\hline \multirow[t]{3}{*}{4} & 5 & 5.62 & 0.45 & 189 & 79 & 0.36 & 0.18 & 580 & 270 & 4.0 & 4.8 & 0.19 & 0.1 & 23.5 & 14.86 \\
\hline & 10 & 5.43 & 0.26 & 119 & 15 & 0.29 & 0.11 & 580 & 337 & 3.3 & 4.3 & 0.48 & 0.89 & 25.1 & 11.58 \\
\hline & 15 & 5.50 & 0.31 & 124 & 5 & 0.92 & 1.68 & 898 & 513 & 8.5 & 14.0 & 0.22 & 0.07 & 14.8 & 9.11 \\
\hline \multirow[t]{3}{*}{5} & 5 & 5.60 & 0.32 & 258 & 26 & 0.64 & 0.26 & 415 & 282 & 5.3 & 4.4 & 0.27 & 0.04 & 10.3 & 5.55 \\
\hline & 10 & 5.60 & 0.46 & 149 & 15 & 1.35 & 1.99 & 727 & 365 & 8.5 & 6.3 & 0.35 & 0.11 & 10.6 & 6.1 \\
\hline & 15 & 5.76 & 0.29 & 144 & 22 & 1.36 & 1.73 & 860 & 286 & 10.8 & 5.2 & 0.31 & 0.06 & 6.71 & 7.12 \\
\hline \multirow[t]{3}{*}{6} & 5 & 7.15 & 0.36 & 1000 & 330 & 9.23 & 5.51 & 780 & 269 & 35.8 & 26.8 & 0.18 & 0.11 & 2.2 & 1.71 \\
\hline & 10 & 6.84 & 0.32 & 738 & 229 & 3.76 & 1.09 & 796 & 248 & 35.0 & 16.4 & 0.15 & 0.06 & 2.22 & 3.49 \\
\hline & 15 & 7.29 & 0.36 & 883 & 82 & 5.53 & 1.56 & 887 & 365 & 26.4 & 10.0 & 0.12 & 0.06 & 2.38 & 3.45 \\
\hline \multirow[t]{3}{*}{7} & 5 & 5.65 & 0.43 & 82 & 51 & 1.13 & 0.42 & 598 & 238 & 3.0 & 2.4 & 0.19 & 0.15 & 14.6 & 6.64 \\
\hline & 10 & 7.20 & 0.30 & 457 & 18 & 3.47 & 1.05 & 850 & 275 & 4.6 & 2.7 & 0.11 & 0.04 & 2.3 & 3.75 \\
\hline & 15 & 6.99 & 0.46 & 396 & 16 & 2.91 & 0.71 & 1165 & 420 & 11.4 & 4.0 & 0.13 & 0.09 & 1.24 & 1.31 \\
\hline 8 & 9 & 5.49 & 0.94 & 167 & 60 & 0.33 & 0.25 & 462 & 229 & 4.5 & 5.9 & 0.15 & 0.15 & 16.5 & 11.31 \\
\hline \multirow[t]{3}{*}{9} & 8 & 7.35 & 0.27 & 1086 & 222 & 7.96 & 5.93 & 750 & 185 & 26.6 & 12.2 & 0.16 & 0.09 & 3.28 & 3.31 \\
\hline & 15 & 7.41 & 0.40 & 3246 & 852 & 9.47 & 24.29 & 547 & 163 & 78.6 & 45.6 & 1.94 & 0.52 & 4.22 & 4.18 \\
\hline & 27 & 6.83 & 0.57 & 36091 & 6509 & 2.28 & 1.23 & 671 & 246 & 81.7 & 31.9 & 0.44 & 0.12 & 2.36 & 3.25 \\
\hline \multicolumn{2}{|c|}{ Mean } & 6.35 & & 1932 & & 7.96 & & 746 & & 36.8 & & 0.53 & & 2.78 & \\
\hline \multicolumn{2}{|c|}{ Median } & 6.43 & & 222 & & 2.91 & & 750 & & 13.0 & & 0.25 & & 2.37 & \\
\hline
\end{tabular}


profiles and relatively uniform in the other two. In most cases, groundwater salinities were always lower than those of the adjacent surf zone.
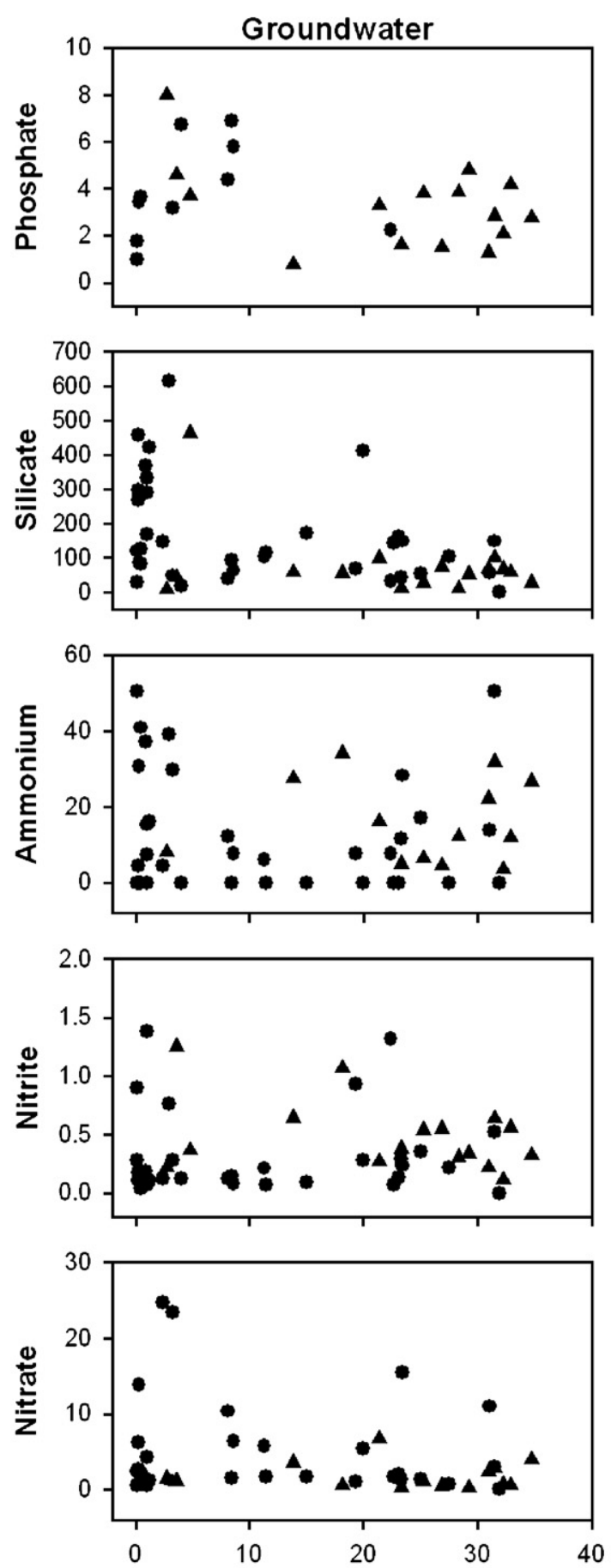

The range in nutrient levels in beach groundwater samples (Fig. 4) is comparable to results of Charette and Sholkovitz (2006) for a subterranean mixing zone on the
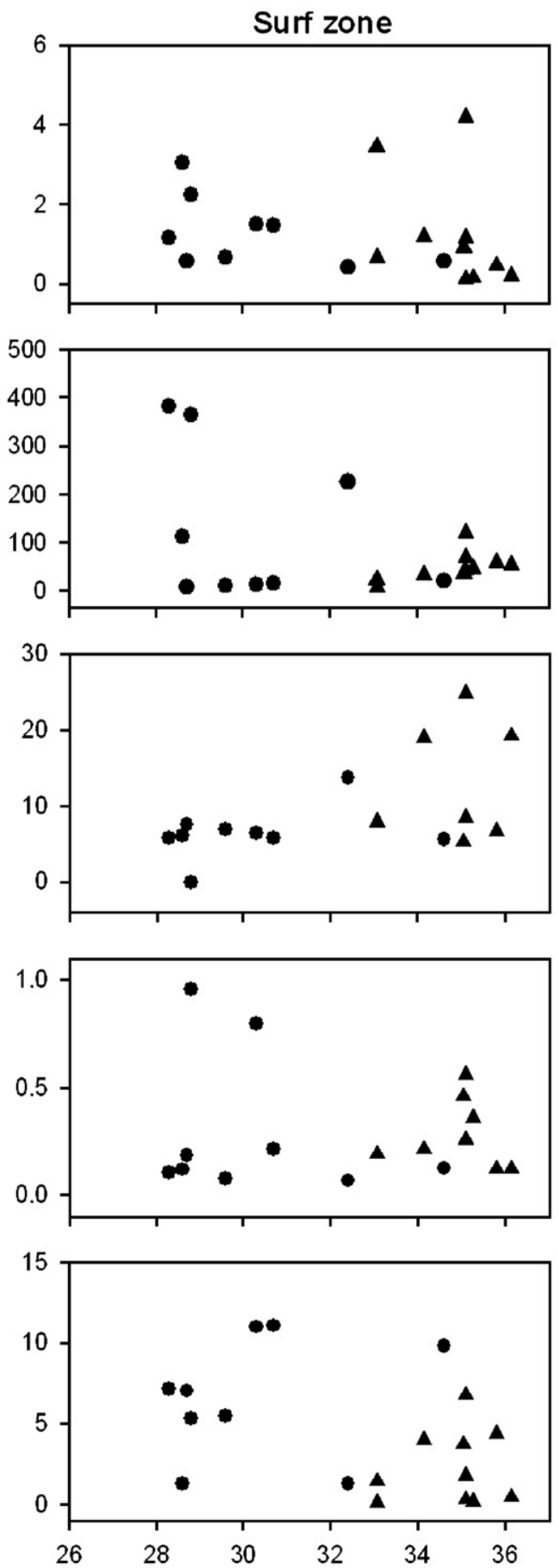

Fig. 4. Concentrations of dissolved nutrients in beach groundwater and in the surf zone (circles — November, 2003; triangles — December, 2004). 
northeastern US coast. Nutrient concentrations in lower salinity samples from the groundwater mixing zone had a range similar to that for samples collected from the
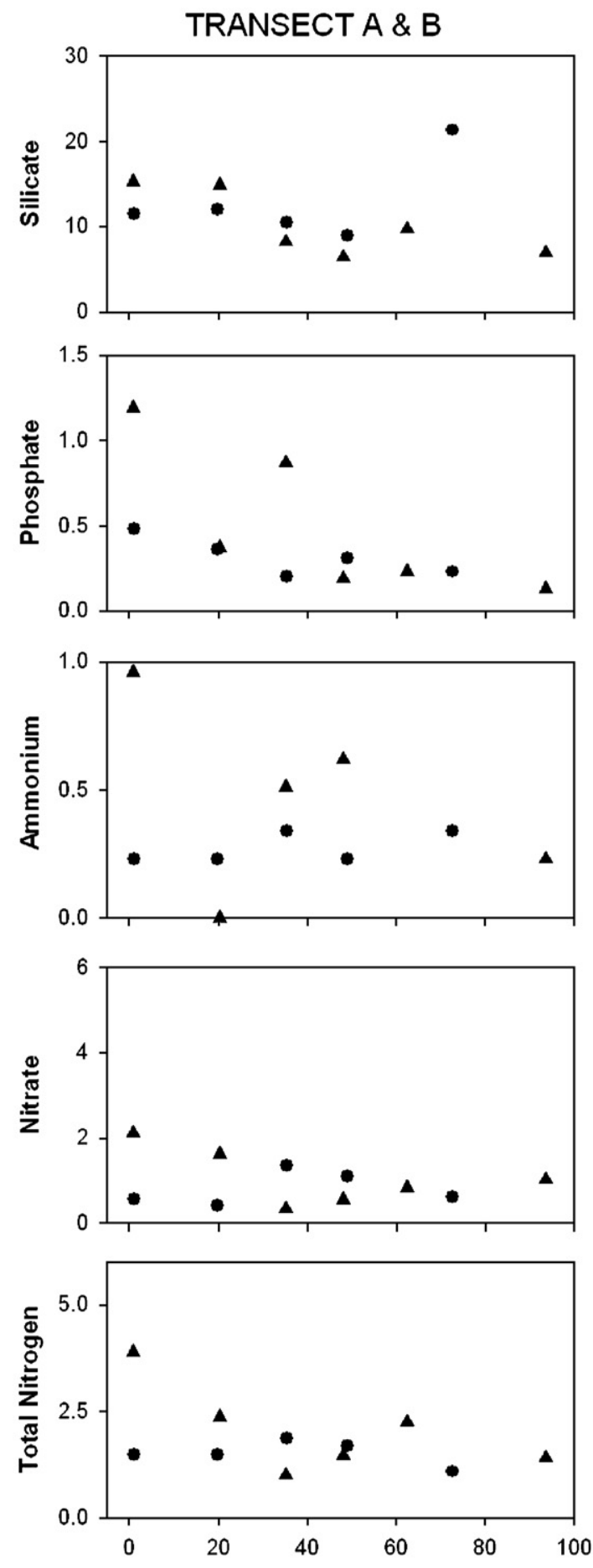

permanent wells; but at higher salinities, concentrations decreased to levels approaching concentrations observed in the adjacent surf zone.

TRANSECT C \& D
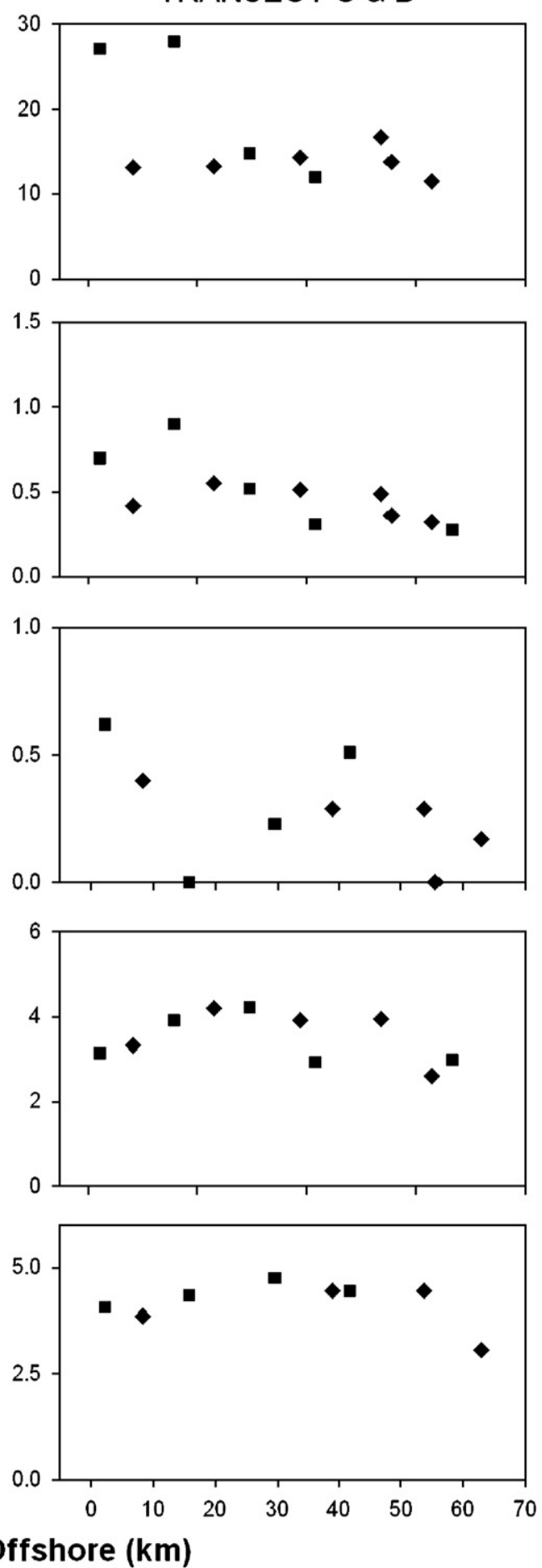

Fig. 5. Cross-shelf variations in dissolved nutrients (Transect A — circles; Transect B — triangles; Transect C — squares; Transect D - diamonds). 


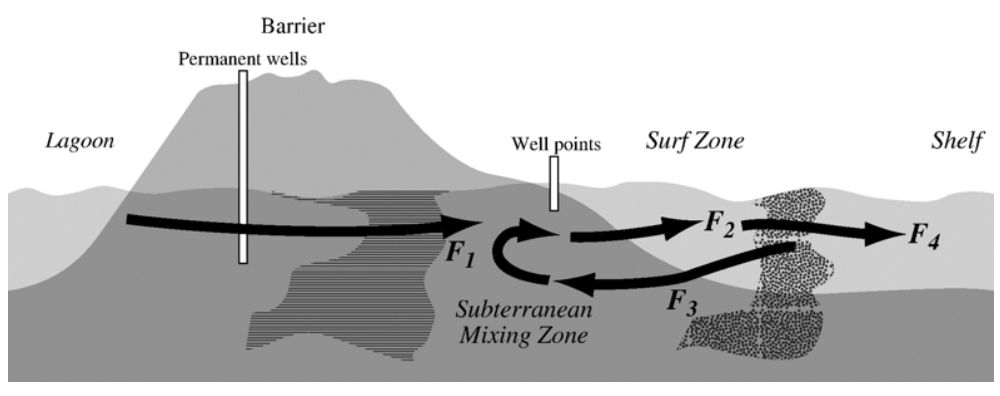

Fig. 6. Conceptual model (not to scale) of nutrient flux in coastal surface water-groundwater system. Flux pathways $F_{1}$ through $F_{4}$ are shown in the diagram. An additional flux pathway to the offshore, $F_{5}$ is not shown.

Diatom blooms observed in the surf zone were always relatively intense (Chlorophyll a: $2.8-470 \mu \mathrm{g}$ $\mathrm{L}^{-1}$; Table 3), suggesting a maintenance of high nutrient concentrations in the surf zone.

\subsection{Offshore samples}

During December 2004 we occupied four $60 \mathrm{~km}$ long offshore transects and one station (\#6) $90 \mathrm{~km}$ offshore (Fig. 1). Samples for nutrient analysis were collected from the upper $5 \mathrm{~m}$ and results are presented in Fig. 5. Here we separate data from the northern and southern transects because density (sigma- $t$ ) profiles from the CTD casts (data not shown but available in Windom et al., 2006) revealed that the two northern transects (A and B) were stratified with a $10-20 \mathrm{~m}$ surface layer separated from bottom waters. The temperature-salinity profile at the most offshore station (6) adjacent to these transect indicates that the water column represents three endmember mixing, composed of one subsurface and two surface water masses: subsurface Subtropical Water (STW, $T=10-20, S=34.2-36$ ), surface Tropical Water (TW, $T>20, S>36$, i.e. Brazil Current) and surface Coastal Water (low $S$ ). This mixing is also evident in the profiles going toward shore on transects $\mathrm{A}$ and $\mathrm{B}$. This suggests that lower salinity coastal water above the pycnocline is mixing with higher salinity offshore water, with both water types having about the same temperature. The STW is isolated as a subsurface water mass separated from the water in the mixed layer by a substantial pycnocline that reduces mixing. Thus, nutrients in surface waters along Transects A and B are more likely to be influenced by the mixing of near shore sources with offshore surface water, as opposed to bottom water inputs. The sigma- $t$ profiles along the two southern transects (Transects C and D), however, indicate a more mixed water column. Thus, surface samples from these transects are also influenced by inputs from the sea bed and/or inputs from Subtropical
Water (STW) due to coastal and shelf break upwelling (Niencheski and Fillmann, 1997). Samples collected along these transects are enriched in $\mathrm{Si}$ (factor of 2) and $\mathrm{NO}_{3}$ (factor of 4) relative to the northern transects. Also, the average temperature of the southern transect surface samples is $1.3{ }^{\circ} \mathrm{C}$ colder than those from the northern transects, another indication of upwelling. However, the average surface salinity of the southern transects is virtually the same as that of the northern ones and not likely influenced by mixing with water from the mouth of Patos Lagoon or the Rio de la Plata.

\section{Discussion}

In the following discussion, we use the data presented above, along with the estimates of submarine groundwater discharge (SGD) from Windom et al. (2006), based on radium isotopic tracers, to estimate the importance of the nutrient flux associated with SGD on the coastal waters of this region. There is obviously large uncertainty in these estimates because of the inherent heterogeneity of this system in time and space. This includes both temporal and spatial variability in nutrient concentrations and advective transport. Constraining our estimates further will require a considerable amount of additional work. Nevertheless, we think that what we present here provides a first order assessment of the importance of the SGD nutrient input to this region and this information should be of interest to researchers working in similar areas elsewhere.

Our conceptual model of how an SGD nutrient flux to the ocean is maintained is as follows: There is a continual supply of nutrients in fresh groundwater, represented by the data from permanent wells, moving toward the coastline, driven by local and/or regional hydraulic gradients. The Patos Lagoon provides the most likely original source of this water by providing a local hydraulic gradient directed toward the South Atlantic along a $c a .240 \mathrm{~km}$ length of coastline of our 
study area. As the nutrient-rich groundwater moves toward the ocean it encounters and mixes with oxygenated seawater that has penetrated into the coastal sand. Although the mixing zone along the shoreline is relatively narrow, this zone must move inland, and perhaps expand, in response to wind-forced high ocean levels. As the winds relax or change directions the mixing zone will move toward the ocean in response to lower ocean water levels (This would lead to the top to bottom decreasing salinity gradients observed in some beach front wells). Winds along this coast usually change directions every 3-7 days. On a longer time, scale seasonal changes in hydraulic gradient between the lagoon and ocean force changes in the position, and probably in the width, of the mixing zone. Thus, changes in the subterranean mixing zone are similar to those encountered in a surface estuary; this is conceptualized in Fig. 6. Finally, fluids from this subterranean mixing zone are discharged to surf zone and shelf waters.

\section{1. $S G D$}

The rate of SGD was estimated by Windom et al. (2006) using radium isotope tracers as summarized below:

Beach groundwater contains high activities of ${ }^{228} \mathrm{Ra}$ (40 to $260 \mathrm{dpm} / 100 \mathrm{~L}$ ), but only moderate activities of ${ }^{226} \mathrm{Ra}(7.1$ to $69 \mathrm{dpm} / 100 \mathrm{~L})$. The surf zone is also enriched in ${ }^{228} \mathrm{Ra}$ (15 to $21 \mathrm{dpm} / 100 \mathrm{~L}$ ) compared to the open ocean ( $5 \mathrm{dpm} / 100 \mathrm{~L})$, but only slightly to not at all enriched in ${ }^{226} \mathrm{Ra}$ (6.9 to $8.9 \mathrm{dpm} / 100 \mathrm{~L}$ ) compared to the open ocean $(7.8 \mathrm{dpm} / 100 \mathrm{~L})$. Moore (2003) has shown that aquifers that are rapidly flushed with salty water contain much higher activities of ${ }^{228} \mathrm{Ra}$ than ${ }^{226} \mathrm{Ra}$. Windom et al. (2006) thus concluded that the surf zone ${ }^{228} \mathrm{Ra}$ enrichments are due to SGD as a result of the dynamic mixing and circulation of freshwater and seawater through the permeable beach/nearshore sands.

Assuming radium addition to coastal surface waters occurs only in the near-shore zone, net cross-shelf advection is zero, cross-shelf mixing is constant, and the system is steady state, the cross-shelf radium isotope gradients in the upper stratified layer of Transects A and B must be balanced by the nearshore SGD flux of radium and radioactive decay (there are no additional inputs from the bottom). Using a model based on these assumptions and the average ${ }^{228} \mathrm{Ra}$ concentration of beach groundwater, Windom et al. (2006) estimated the SGD to be $8.5 \times 10^{7} \mathrm{~m}^{3}$ day $^{-1}$ for the $240 \mathrm{~km}$ study coastline. The average salinity of the SGD was assumed to be 22.9, the average of the beach groundwater, while that of the surf zone was 34.6. Thus, based on salt balance, $3.1 \times 10^{7} \mathrm{~m}^{3}$ day $^{-1}$ is the freshwater component $\left(Q_{\mathrm{fw}}\right)$ of the SGD. The remainder $\left(5.4 \times 10^{7} \mathrm{~m}^{3}\right.$ day $\left.^{-1}\right)$ must be balance by recirculated seawater, so that:

$\mathrm{SGD}=Q_{\mathrm{fw}}+Q_{\mathrm{sw}}$.

Where $Q_{\text {sw }}$ is the seawater flux into the permeable sands that is ultimately recycled in the SGD. And for mass balance, assuming steady state, the net offshore transport of water due to mixing must equal $Q_{\mathrm{fw}}$.

\subsection{Nutrient fluxes}

Referring to the conceptual model presented in Fig. 6, we can estimate the nutrient flux associated with the various water fluxes discussed above. These fluxes include: (1) fresh groundwater moving toward the ocean $\left(F_{1}\right)$, (2) SGD entering the ocean $\left(F_{2}\right),(3)$ seawater recirculating through permeable sediments $\left(F_{3}\right),(4)$ the flux to the inner shelf $\left(F_{4}\right)$, and (5) the offshore flux $\left(F_{5}\right)$. These can be estimated using the following equations:

$$
\begin{aligned}
F_{1} & =[C]_{\mathrm{fw}} \times Q_{\mathrm{fw}} \\
F_{2} & =[C]_{\mathrm{bgw}} \times \mathrm{SGD} \\
F_{3} & =[C]_{\mathrm{sz}} \times\left(\mathrm{SGD}-Q_{\mathrm{fw}}\right) \\
F_{4} & =\left\{[C]_{\mathrm{bgw}} \times \mathrm{SGD}\right\}-\left\{[C]_{\mathrm{sz}} \times\left(\mathrm{SGD}-Q_{\mathrm{fw}}\right)\right\} \\
& =F_{2}-F_{3} \\
F_{5} & =\left\{[C]_{\text {shelf }}-[C]_{\text {ocean }}\right\} \times\left(V_{\text {surface layer }} / \tau\right) .
\end{aligned}
$$

Where $[C]_{\mathrm{fw}},[C]_{\mathrm{bgw}}[C]_{\mathrm{sz}},[C]_{\text {shelf }}$, and $[C]_{\mathrm{ocean}}$ are the mean concentrations of a given nutrient in permanent wells, beach groundwater, surf zone, inner shelf, and ocean, respectively. $V_{\text {surface layer }}$ is the volume of the inner shelf surface layer $(240 \mathrm{~km} \times 22 \mathrm{~km} \times 10 \mathrm{~m})$ used by Windom et al. (2006) to calculate a residence time, $\tau$, of 8.3 days based on radium isotopic tracers. Because we only have radium tracer data from our December 2004 campaign, from which we can estimate SGD, the flux estimates presented below are based only on the results from samples collected during that campaign. However, for the flux from fresh groundwater, $F_{1}$, we use all of the permanent well sample data, which we believe is more representative of the composition of this source.

\subsubsection{Fluxes in fresh groundwater $\left(F_{1}\right)$}

Using Eq. (1) we calculate the nutrient fluxes in the fresh groundwater, as represented by the permanent well samples, that is moving toward the ocean. We used the 
Table 2

Estimated nutrient fluxes to the coast. $F_{1}$, in fresh groundwater compared to surface freshwater nutrient inputs to Patos Lagoon $\left(10^{6} \mathrm{~mol} \mathrm{day}^{-1}\right)$

\begin{tabular}{lcl}
\hline & $F_{1}$ & $\begin{array}{l}\text { Freshwater nutrient flux to Patos Lagoon } \\
\text { (Niencheski and Windom, 1994) }\end{array}$ \\
\hline Silicate & 23.2 & 13.1 \\
Phosphate & 0.25 & 0.05 \\
Ammonium & 1.15 & 0.25 \\
Nitrite & 0.002 & 0.01 \\
Nitrate & 0.086 & 0.98 \\
Total nitrogen & 1.25 & 1.24 \\
\hline
\end{tabular}

mean nutrient concentrations provided in Table 1, recognizing that normalizing concentrations observed for each well relative to groundwater flow at that site would provide more constrained flux estimates. But, at this time we do not have estimates of groundwater flow paths or velocities. Regardless, the regional nutrient fluxes we calculate using this approach are compared with those to Patos Lagoon associated with freshwater input (Table 2). Nitrate is the only nutrient species for which the $\mathrm{F}_{1}$ groundwater flux is considerably less than the surface freshwater flux to Patos Lagoon, but this appears to be compensated by the ammonium flux so that the total nitrogen fluxes are similar.

Given the long residence time of water in Patos Lagoon (Niencheski and Windom, 1994), a significant amount of the freshwater input of fixed nitrogen could be removed by denitrification. This would require additional sources to account for the $F_{1}$ nitrogen flux. Although anthropogenic sources are possible, the largest likely contributors are agricultural runoff and the city of Porto Alegre at the north of the lagoon, both of which should be accommodated in the estimate of "freshwater inputs" by Niencheski and Windom (1994). This implies that other sources such as diagenesis of organic deposits within the barrier are available or that the anthropogenic sources on the barrier are more important than we think. But the latter is restricted to a few small villages with a total population of a few thousand, minimal row crop agriculture, livestock grazing and silviculture (pines) which covers less than $10 \%$ of the area of the barrier. If these were important we would expect that the nutrient concentrations observed in the southernmost wells, where these anthropogenic sources are most concentrated, would be highest. Only ammonium concentrations in samples from wells at Station 9 stand out as uniquely higher than concentrations observed elsewhere.

While lagoon systems are commonly considered to be nutrient traps (Monbet, 1992; Rabalais et al., 1996), the remineralization of organic matter in lagoon sediments followed by subterranean advection is probably not sufficient to support the $F_{1}$ nitrogen groundwater flux. The $\mathrm{N}$ flux, and the phosphate and silicate fluxes, clearly require their mobilization from organic matter and/or mineral deposits within the barrier or from other sources.

5.2.2. $F_{2}, F_{3}, F_{4}$, and $F_{5}$; flux associated with $S G D$, recirculated seawater, transport to the inner shelf and transport offshore

The ocean surf zone samples show no relation between salinity and distance from the mouth of Patos Lagoon (Table 3) and, in fact, some samples collected furthest from the mouth of the lagoon had the lowest salinities. Since there are no other obvious major sources of fresh

Table 3

Nutrient concentrations in beach groundwater and surf zone samples with distance north of the mouth of Patos Lagoon

\begin{tabular}{|c|c|c|c|c|c|c|c|c|c|c|c|c|c|}
\hline \multicolumn{7}{|c|}{ Beach groundwater ${ }^{a}$} & \multicolumn{7}{|c|}{ Surf zone } \\
\hline & Salinity & $\mathrm{PO} 4$ & $\mathrm{SiO} 2$ & NH4 & $\mathrm{NO} 2$ & $\mathrm{NO} 3$ & Salinity & $\mathrm{PO} 4$ & $\mathrm{SiO} 2$ & NH4 & $\mathrm{NO} 2$ & $\mathrm{NO} 3$ & Chl $a$ \\
\hline \multicolumn{2}{|l|}{$\mathrm{km}$} & $\mu \mathrm{M}$ & $\mu \mathrm{M}$ & $\mu \mathrm{M}$ & $\mu \mathrm{M}$ & $\mu \mathrm{M}$ & & $\mu \mathrm{M}$ & $\mu \mathrm{M}$ & $\mu \mathrm{M}$ & $\mu \mathrm{M}$ & $\mu \mathrm{M}$ & $\mu \mathrm{g} / \mathrm{L}$ \\
\hline 20 & 18.2 & 31.83 & 57.0 & 34.1 & 1.07 & 0.62 & 33.5 & 0.75 & 15.8 & 2.67 & 0.17 & 2.40 & 97 \\
\hline 40 & & & & & & & 34.0 & 0.60 & 37.5 & 2.32 & 0.19 & 2.20 & 115 \\
\hline 60 & 2.7 & 8.02 & 7.8 & 8.0 & 0.22 & 1.45 & 35.3 & 3.46 & 22.5 & 7.77 & 1.28 & 0.15 & 114 \\
\hline 80 & 27.3 & 3.87 & 11.1 & 12.2 & 0.31 & 44.58 & 32.8 & 0.67 & 7.8 & 8.03 & 0.19 & 1.45 & 220 \\
\hline 100 & 4.2 & 4.16 & 253.3 & & 0.81 & 25.29 & 32.2 & 1.18 & 32.4 & 19.0 & 0.22 & 4.02 & 470 \\
\hline 120 & 30.8 & 4.18 & 57.8 & 11.9 & 0.56 & 0.57 & 33.5 & 4.18 & 119.6 & 43.1 & 0.56 & 1.82 & 80 \\
\hline 140 & 33.5 & 2.81 & 64.2 & 29.3 & 0.48 & 3.43 & 33.0 & 0.45 & 58.2 & 6.70 & 0.12 & 4.39 & 55 \\
\hline 160 & 13.5 & 0.79 & 57.8 & 27.5 & 0.64 & 3.58 & 36.5 & 0.92 & 35.7 & 5.34 & 0.46 & 3.76 & 110 \\
\hline 180 & 24.5 & 3.55 & 63.5 & 11.3 & 0.41 & 3.89 & 36.4 & 1.15 & 42.4 & 24.9 & 0.26 & 6.81 & 99 \\
\hline 200 & 31.1 & 1.68 & 68.3 & 12.8 & 0.17 & 1.55 & 36.8 & 0.11 & 68.1 & 8.51 & 0.26 & 0.30 & 44 \\
\hline 220 & 22.4 & 3.22 & 33.0 & 44.6 & 0.36 & 0.31 & 35.9 & 0.15 & 47.0 & 44.2 & 0.36 & 0.21 & 6 \\
\hline 240 & 25.9 & 1.51 & 74.4 & 4.5 & 0.55 & 0.54 & 35.6 & 0.20 & 54.0 & 19.2 & 0.12 & 0.49 & 109 \\
\hline Mean & 22.9 & 5.97 & 68.0 & 19.6 & 0.51 & 7.80 & 34.6 & 1.15 & 45.1 & 16.0 & 0.35 & 2.33 & 127 \\
\hline Median & 23.7 & 3.71 & 60.7 & 12.8 & 0.50 & 2.49 & 34.6 & 0.75 & 42.4 & 8.5 & 0.26 & 2.20 & 109 \\
\hline
\end{tabular}

${ }^{\text {a }}$ Mean for samples from all depths. 
surface water (only a minimal number of small transient streams drain the barrier), we conclude that SGD from the permeable barrier selectively reduces the ocean salinity along this coastline.

To calculate the various nutrients fluxes, we use the data presented in Table 3, which are based on samples collected in December, 2004. These samples were collected 20-240 km from the mouth of Patos Lagoon and, like salinity, nutrient concentrations showed no relation to distance. Using Eqs. (2) and (3) we can calculate the nutrient fluxes associated with SGD and recirculated seawater (i.e. $F_{2}$ and $F_{3}$ ), and by difference of these two fluxes we can estimate a potential transport to the shelf $\left(F_{4}\right.$, Eq. (4)).

We can also calculate the offshore flux of total inorganic nitrogen, silicate and phosphate using Eq. (5) and a water residence time of 8.3 days (Windom et al., 2006) and mean concentrations of total $\mathrm{N}(1.82 \mu \mathrm{M})$, phosphate $(0.41 \mu \mathrm{M})$ and silicate $(11.45 \mu \mathrm{M})$ in inner shelf surface waters from Transect A and B. We use the concentrations of these nutrients in Station 6 samples $(\mathrm{N}=1.42 \mu \mathrm{M}, \mathrm{P}=0.13 \mu \mathrm{M}, \mathrm{Si}=6.96 \mu \mathrm{M})$ as the "ocean concentration". The results of these calculations are compared with the fresh groundwater flux, $F_{1}$, in Table 4. In this table we also estimate fluxes based on median concentrations of permanent well (Table 1) and beach groundwater and surf zone samples (Table 3 ).

Once introduced to the surf zone in SGD, $F_{2}$, nutrient concentrations decrease due to mixing with surface water of lower concentrations and/or by phytoplankton uptake. But because of the dynamics within the coastal zone, significant nutrient fluxes back into the permeable sediments, $F_{3}$, and offshore from the surf zone, $F_{4}$, must occur. For total nitrogen and phosphate, the fresh groundwater flux, $F_{1}$, is similar to the estimated flux that escapes the surf zone to the inner shelf, $F_{4}$. This implies that nitrogen and phosphate are completely remobilized in the nearshore region during the reminerialization of the intense primary production.

For silicate, $F_{1}$ is much greater than $F_{4}$, indicating that removal is an important process in the nearshore.
Silicate may be biologically removed as biogenic silica at this interface and likely would not remineralize as rapidly as $\mathrm{N}$ and $\mathrm{P}$ so that the rapid nutrient cycling associated with the high rate of primary production and microbial degradation in the surf zone may provide an efficient mechanism for silica trapping. But given a Redfield ratio of C:Si:N:P (106:15:16:1) for diatoms (Redfield et al., 1963) and the total $\mathrm{N}$ flux in SGD, nitrogen would need to cycle through production and remineralization ten times in this zone to account for the apparent Si removal, assuming it is irreversibly removed during production. While this process may account for much of the Si removal, we think that other processes are likely involved. Scavenging on particles associated with the precipitation of iron, which is important in this region (Windom et al., 2006) may be one such process.

The two northern Transects A and B, for which the above nutrient fluxes are estimated, were stratified with a 10-20 m surface layer separated from bottom waters suggesting little influence of inputs from the sea bed. It is this region where the influence of SGD from nearshore permeable sediments is expected to be the most significant. But it is clear from the estimates given in Table 4 that the nutrient fluxes to the inner shelf, $F_{4}$, are on the order of $10 \%(\mathrm{Si})$ to $55 \%$ (total $\mathrm{N}$ ) of the amount needed to balance the flux offshore, $F_{5}$. These are still significant contributions to the nutrient budget for this coastal ocean region.

\subsubsection{Uncertainty of flux estimates}

We acknowledge that there are considerable uncertainties in the flux calculations made above. As we have mentioned earlier, there is likely more than one fresh groundwater system active in the region and flow is likely heterogeneous in direction and velocity within the barrier. Within the beach groundwater freshwater-sea water mixing zone, we have no clear understanding of the pathways of the various mixtures transported from and to the permeable sands. We could have used the minimum concentration values for each of the reservoirs in the flux calculations equations and compared that to

Table 4

Estimated nutrient fluxes $\left(\times 10^{6} \mathrm{~mol} \mathrm{day}^{-1}\right)$ as shown in Fig. 6 using mean and median reservoir nutrient concentrations

\begin{tabular}{|c|c|c|c|c|c|c|c|c|c|c|}
\hline & $F_{1}$ & $F_{1}$ & $F_{2}$ & $F_{2}$ & $F_{3}$ & $F_{3}$ & $F_{4}$ & $F_{4}$ & $F_{5}$ & $F_{5}$ \\
\hline & Mean & Median & Mean & Median & Mean & Median & Mean & Median & Mean & Median \\
\hline Silicate & 23.2 & 23.3 & 5.92 & 5.28 & 2.53 & 2.37 & 3.39 & 2.91 & 28.7 & 22.5 \\
\hline Phosphate & 0.25 & 0.09 & 0.52 & 0.32 & 0.06 & 0.04 & 0.46 & 0.28 & 1.7 & 1.15 \\
\hline Ammonium & 1.15 & 0.4 & 1.71 & 1.11 & 0.89 & 0.48 & 0.81 & 0.63 & & \\
\hline Nitrite & 0.002 & 0.0007 & 0.044 & 0.04 & 0.019 & 0.015 & 0.025 & 0.025 & & \\
\hline Nitrate & 0.086 & 0.074 & 0.67 & 0.22 & 0.13 & 0.12 & 0.54 & 0.1 & & \\
\hline Total nitrogen & 1.25 & 0.49 & 2.42 & 1.37 & 1.04 & 0.61 & 1.39 & 0.76 & 2.5 & 0.38 \\
\hline
\end{tabular}


calculations using the maximum observed concentrations to assess a range or uncertainty in flux calculations, but thought that this would not be very instructive. Instead we used mean concentrations (which assumes normal distribution of the parameters) of the various reservoirs to make the flux calculations to assess the significance of the groundwater flux to coastal surface waters. We understand that mean nutrient concentrations of the reservoirs do not reflect their heterogeneity and inherited flux calculation uncertainties; therefore, we calculated fluxes using median values as well (Table 4). This approach would yield flux estimates reflecting the skewing of the concentration distributions observed in the various reservoirs. Thus a comparison with fluxes based on mean and median concentrations may provide a more reasonable view of the degree of uncertainty in the calculations. This comparison suggests that with the exception of the $F_{1}$ phosphate flux, the differences in the silicate and phosphate fluxes are not likely as uncertain as the total nitrate fluxes, which are approximately $50 \%$ lower using median concentrations.

\subsubsection{The southern transects}

We have focused on the northern Transects (A and B) because the water column was stratified and hence, the offshore transport in the surface layer could be modeled and fluxes determined (Windom et al., 2006). These fluxes indicate considerable SGD nutrient input to the surf zone, but this near-shore SGD cannot account for all of the offshore fluxes $\left(F_{5}\right)$, particularly for silicate. This fact and the observation that higher nutrient concentrations were present along the southern transects require additional sources of nutrients to this region. The freeflowing wells on the barrier indicate a considerable piezometric head is present in parts of the aquifer system. This could drive discharge from the aquifer onto the shelf. Moore et al. (2002) reported SGD inputs of nutrients on the shelf of the southeastern US coast $20 \mathrm{~km}$ from shore. Because of the stratification along the northern transects, the effects of SGD input on the shelf were not considered. Neither did we consider upwelling of subtropical water (STW). STW is a major source of dissolved nitrate, with a mean concentration of $9.29 \mu \mathrm{M}$ and a range between 0.22 and $26.28 \mu \mathrm{M}$. This water is also rich in dissolved inorganic phosphate (mean $0.73 \mu \mathrm{M}$, maximum $1.81 \mu \mathrm{M}$ ) (Niencheski and Fillmann, 1997). During spring and summer coastal upwelling is more frequent, owing to the strong influence of NE winds, which initiates the intrusion of STW onto the shelf. During spring, upwelling at the shelf break may also occur. And the Brazil Current and the coastal branch of Malvinas Current (MC) form frontal vortices of cyclonic circulation which cause upwelling of bottom water, principally STW (Garcia, 1997), producing sub-surface and surface nuclei of high biomass (Ciotti et al., 1995). Either of these mechanisms could account for the higher nutrient concentrations along the southern transects.

\subsection{Coastal primary production}

Along the southern Brazil coast the phytoplankton production in the surf zone is characteristically dominated by frequent and dense accumulations of the diatom A. glacialis, and diatom patches are a typical feature of the surf zones. The development of $A$. glacialis patches along the southern Brazilian coast is related to cyclic cold front passages with strong southerly winds, which force seawater onshore and generate high-energy waves and a wider surf zone. Under these conditions, high concentrations of $A$. glacialis cells are resuspended from nearshore sediments and, owing to the high wave energy, accumulate in the surf zone, where exposure to intense light stimulates further cell growth. Rip currents and undertow return the diatom cells to nearshore sediments beyond the surf zone, where they accumulate under calm conditions (Odebrecht et al., 1995).

Mesoscale cycles of Asterionellopsis glaciallis patch formation are accompanied by extreme fluctuations in chlorophyll $a$ concentrations from 1.2 to $1600 \mu \mathrm{g} \mathrm{L}^{-1}$; (Odebrecht et al., 1995), similar to the range we observed in the surf zone (6.5 to $470 \mu \mathrm{g} \mathrm{L}^{-1}$; Table 3). Although information on phytoplankton primary production levels is lacking, we can estimate the potential production rate sustained by the SGD nitrogen flux, $F_{2}$ (Table 4). Thus a nitrogen flux of $2.4 \times 10^{6} \mathrm{~mol} \mathrm{~N} \mathrm{day}^{-1}$ would support a production rate of $1.9 \times 10^{8} \mathrm{~g} \mathrm{C}$ day $^{-1}$. If we assume a surf zone of $240 \mathrm{~km} \times 100 \mathrm{~m}$ this production rate becomes $c a$. $3000 \mathrm{~g} \mathrm{C} \mathrm{m}^{-2}$ year $^{-1}$. This rate is similar to that observed in salt marsh and mangrove ecosystems and is significantly larger than commonly reported for estuarine waters. But only about half of this can be considered "new" production given that much of the inorganic nitrogen in SGD is from recycled seawater as represented as $F_{3}$ in Fig. 6 and listed in Table 4.

\section{Conclusions}

The results reported here show that SGD may provide an important flux of nutrients to coastal ocean regions characterized by permeable sediments such as barriers of coastal lagoons. They also suggest that the subterranean transport pathway may be important in explaining the nutrient budgets of coastal lagoons. 
Our results also show that groundwater transport, seawater cycling through permeable coastal/shelf sediments, and SGD along the coast of Southern Brazil are more complex than we originally hypothesized. Instead of SGD being driven simply by a surficial aquifer, which links the lagoon to the ocean, an additional aquifer system(s) underlies this region and may support SGD over a wider region of the shelf.

Under the assumption that nitrogen limits production in the nearshore, surf zone region, the SGD flux can support a production rate of about $8 \mathrm{~g} \mathrm{C} \mathrm{m}^{2}$ day $^{-1}$ or ca. $3000 \mathrm{~g} \mathrm{C} \mathrm{m}^{2}$ year $^{-1}$.

\section{Acknowledgements}

The authors wish to thank Debbie Wells, Mary Richards, Julie Amft, Elisa Fernandes, Vanderlen Miranda, Lucia Bohmer and Idel Milani for their assistance in field sampling and analyses. We also thank the students and staff of FURG and the captain and crew of $R / V$ Atlantico do Sul. This work was support in part by the National Science Foundation (OCE-0233465, HLW and RAJ, OCE-0233657, WSM) and CNPq (Brazil — Grants 490126/2003-0 and 301219/2003-6).

\section{References}

Aminot, A., Chaussepied, M., 1983. Manuel des analyses chimiques en milieu marin. CNEXO, Brest, p. 396.

Araújo, L.M., França, A.B., Potter, P.E., 1999. Hydrogeology of the Mercosul aquifer system in the Paraná basin, South America, and comparison with the Navajo-Nugget aquifer system, USA. Hydrogeol. J. 7, 317-336.

Barnes, R.S.K., 1980. Coastal Lagoons. Cambridge University Press, Cambridge. 106 pp.

Calliari, L., Gomes, M.E.V., Griep, G.H., Moller, O.O., 1980. Caracteristicas Sedimentologicas e Fatores Ambientais da Regiao Estuarial da Lagoa dos Patos. Anais Do XXXI Congresso Brasileiro de Geologia, Balneario de Camburio, Santa Catarina, vol. 2, pp. 862-875.

Charette, M.A., Sholkovitz, E.R., 2006. Trace element cycling in a subterranean estuary: part 2. Geochemistry of the pore water. Geochim. Cosmochim. Acta 70 (4), 811-826.

Ciotti, A.M., Odebrecht, C., Fillmann, G., Moller, O.O., 1995. Freshwater waterflow and Subtropical Convergence Influence on phytoplankton biomass on the southern Brazilian continental shelf. Cont. Shelf Res. 15 (14), 1737-1736.

Corbett, D.R., Chanton, J., Burnett, W., Dillon, K., Rutkowski, C., Fourqurean, J.W., 1999. Patterns of groundwater discharge into Florida Bay. Limnol. Oceanogr. 44 (4), 1045-1055.

D’Elia, C.F., Webb, K.L., Porter, J.W., 1981. Nitrate-rich groundwater inputs to Discovery Bay, Jamaica: a significant source of $\mathrm{N}$ to local reefs? Bull. Mar. Sci. 31, 903-910.

Dillenburg, S.R., Roy, P.S., Cowell, P.J., Tomazelli, L.J., 2002. Influence of Antecedent Topography on Coastal Evolution as Tested by the Shoreface Translation-Barrier Model (STM). J. Coast. Res. 16, 71-81.
Garcia, C.A.E., 1997. Physical Oceanography. In: Seeliger, U., Odebrecht, C., Castello, J.P. (Eds.), Ecology of Subtropical Convergence Regions - The Coast and Sea in the Warm-temperate Southwestern Atlantic. Chapter: Coastal and Marine Environments and Their Biota. Springer-Verlag, pp. 166-170.

Gianuca, N. (1983) A preliminary account of the ecology of sandy beaches in southern Brazil. P. 413-419, in "Sandy Beaches as Ecosystems", ed. By McLachlan A., Erasmus T.; W. Junk, The Hague, 761 p.

Herrera-Silveira, J.A., 1998. Nutrient-phytoplankton production relationships in a groundwater-influenced tropical coastal lagoon. Aquat. Ecosyst. Health Manag. 1, 373-385.

Herz, R., 1997. Circulacao das aguas de superficie da Lagoa dos Patos. Ph.D. Thesis. Universidade de Sao Paulo, Sao Paulo, Brazil.

Jahnke, R.A., Alexander, C.R., Kostka, J.E., 2003. Advective pore water input of nutrients to the Satilla River Estuary, Georgia, USA. Estuar. Coast. Shelf Sci. 56, 641-653.

Johannes, R.E., Hern, C.J., 1985. the effect of submarine groundwater discharge on nutrient and salinity regimes in a coastal lagoon off Perth, Western Australia. Estuar. Coast. Shelf Sci. 21, 789-800.

Kjerfve, B., 1986. Comparative oceanography of coastal lagoons. In: Wolde, D.A. (Ed.), Estuarine Variability. Academic Press, New York, pp. 63-81.

Knoppers, B., Kjerfve, B., 1999. Coastal lagoons of Southeastern Brazil: physical and biogeochemical characteristics. In: Perillo, G.M.E., Piccolo, M.C., Pino-Quivira, M. (Eds.), Estuaries of South America, Their Geomorphology and Dynamics. Springer Press. 31 pp.

Moller, O.O., Castaing, P., Salomon, J.C., Lazure, P., 2001. The Influence of Local and Non-Local Forcing Effects on the Subtidal Circulation of Patos Lagoon.

Moller, O.O., Lorenzzentti, J.A., Stech, J.L., Mata, M.M., 1996. The Patos-lagoon summertime circulation and dynamics. Cont. Shelf Res. 16, 335-351.

Monbet, Y., 1992. Control of phytoplankton biomass in estuaries: a comparative analysis of microtidal and macrotidal estuaries. Estuaries 15, 563-571.

Moore, W.S., 1999. The subterranean estuary: a reaction zone of ground water and sea water. Mar. Chem. 65, 111-126.

Moore, W.S., 2003. Sources and fluxes of submarine groundwater discharge delineated by radium isotopes. Biogeochemistry 66, 75-93.

Moore, W.S., Krest, J., Taylor, G., Roggenstein, E., Joye, S., Lee, R., 2002. Thermal evidence of water exchange through a coastal aquifer: implications for nutrient fluxes. Geophys. Res. Lett. 29. doi:10.1029/2002GL014923.

Niencheski, L.F., Fillmann, G., 1997. Chemical characteristics. In: Seeliger, U., Odebrecht, C., Castello, J.P. (Eds.), Ecology of Subtropical Convergence Regions - The Coast and Sea in the Warm-temperate Southwestern Atlantic. Chapter: Coastal and Marine Environments and their Biota. Springer-Verlag, pp. 96-98.

Niencheski, L.F., Windom, H.L., 1994. Nutrient flux and budget in Patos Lagoon Estuary (Brazil). Sci. Total Environ. 149, 53-60.

Odebrecht, C., Segatto, A.Z., Freitas, C.A., 1995. Surf-zone chlorophyll $1 a$ variability at Cassino Beach, Southern Brazil. Estuar. Coast. Shelf Sci. 41, 81-90.

Piola, A.R., Matano, R.P., Palma, E.D., Möller Jr., O.O., Campos, E.J.D., 2005. The influence of the Plata River discharge on the western South Atlantic shelf. Geophys. Res. Let. 32. doi:10.1029/2004GL021638.

Rabalais, N.M., Turner, R.E., Dortch, Q., 1996. Nutrient changes in Mississippi River and system responses on the adjacent continental shelf. Estuaries 19, 386-407.

Redfield, A.C., Ketchum, B.H., Richard, F.A., 1963. The influence of organisms on the composition of seawater. In: Hill, M.N. (Ed.), The Sea, vol. 2. Wiley Interscience, New York, pp. 26-77. 
Rutkowski, C.M., Burnett, W.C., Iverson, R.L., Chanton, J.P., 1999. The effect of groundwater seepage on nutrient delivery and seagrass distribution in the Northeastern Gulf of Mexico. Estuaries 22 (4), 1033-1040.

Simmons Jr., G.M., 1992. Importance of submarine ground water discharge (SGWD) and seawater cycling to material flux across sediment/water interfaces in marine environments. Mar. Ecol., Prog. Ser. 84, 173-184.

Strickland, J.D.H., Parsons, T.R., 1967. A Practical Handbook of Seawater analysis. Fisheries Research Board of Canada Bulletin.

Todd, D.K., 1970. The Water Encyclopedia. In: Todd, David Keith (Ed.), A Compendium of Useful Information on Water Resources. Water Information Center, Port Washington, N.Y. (559 pp.).
Windom, H., Niencheski, L.F., 1994. Nitrogen flux and budget in the Patos Lagoon estuary. Sci. Total Environ. 149, 53-60.

Windom, H., Niencheski, L.F., 2003. Biogeochemistry in a freshwater-seawater mixing zone in permeable sediments along the coast of Southern Brazil. Mar. Chem. 83, 121-130.

Windom, H., Moore, W.S., Niencheski, L.F., Jahnke, R., 2006. Submarine groundwater discharge: a large, previously unrecognized source of dissolved iron to the South Atlantic Ocean. Mar. Chem. 102, 252-266. 